the Committee of the Privy Council for Scientific and Industrial Research. The report of the Universities Trust exhibits the effective response of the universities to recent calls. The report of the Council makes very evident the need, long recognised by scientific men, of change-drastic change-in the methods of industry, and the need for collaboration in endeavour. It makes also very evident the need for the theorist to direct and expedite the labours of the practical man; and, more satisfactory still, it shows that the practical man is now recognising it widely under the stress of war.

The future age is to be the age of specialisation and co-ordination. An interesting example of co-ordination appears in the reports of the Advisory Council and the United Kingdom Trust. The former body gave grants to the Stoke School of Pottery in order to aid "a threatened industry." The latter acquired the unique Solon Ceramic Library and presented it to the Stoke School in the hope that it might "help to strengthen the high standard of a national industry."

The specialisation and the co-ordination are to be directed towards the placing of national efforts on the fittest bases and in touch with the fittest methods. It is largely isolation and the lack of specialised scientific control in commercial and industrial endeavours that have led to the critical conditions upon which the war has focussed attention. The Committee of the Privy Council has already done much towards the removal of some of these conditions, and has proceeded tentatively to the inauguration of means to remedy widely the lack of co-ordination and the neglect of specialised control. The constitution of the machinery of the committee for the effective attainment of its national aims is very ideal. The committee itself includes the heads of the various governmental departments concerned, and its Advisory Council and very large Standing Committees are formed of working scientific and technical experts, whose decisions must obviously be determinative.

But there exist many pre-war administrations - boards, trusts, etc.- on a smaller scale, and many post-war administrations will arise also on a smaller scale, yet, nevertheless, dealing with matters of importance to the nation. In the case of the former there must be revision, in the case of the latter there must be supervision, in order that the fittest constitution may be framed and followed. In matters of business the framing should be moulded on business lines, and not, for example, on legal lines, though a slight admixture of legal opinion might be desirable. In matters of education the administrators should mainly be trained educationists, and not, for example, business men, though a slight proportion of these might be of advantage when the administration deals also with its own funds. In a mixed body it is not infrequently found that the best business member is one who never had a special business training; nevertheless, there are certain aspects of business which can be NO. 2483 , VOL. 99] safely guided only by a trained specialist. On the other hand, it must also be recognised that the lines of success in a trading firm or a manufacturing firm are fundamentally different from those in an educational institution. Trade and ordinary business are of the nature of a war with tendencies, which may be, and often are, successfully combated, towards selfishness and hardness. And this tendency might easily develop into a national curse. In not very remote history a subordinate body, composed mainly of business men, intending to be well-intentioned, but misled by a mischief-maker and to some extent under the influence of the heritage of old feuds, worked behind the back of a superior body and almost involved both bodies in an utterly ruinous litigation. In that process they attacked, also behind his back and without his knowledge, a man whose life, in connection with the matter regarding which they attacked him, could easily challenge that of any one of them; for it had, in that very matter, been one of absolute innocence. Such a performance could scarcely be imagined in the case of a body of jurists, whose training begets sensitiveness to justice; or of a body of scientific men, whose training begets sensitiveness to accuracy and truth; or even of a body of literary men or artistic men, whose training confirms the sense of beauty.

In every case the scientific test of fitness must be applied. In pure business, the business man; in pure technics, the technical man; in technical science, the practical man and the man of science equally, or the latter preponderantly in cases of doubt; in education, the trained educationist, must have the determinative voice. So also in other matters. It is no less an important point that the specialists must be men actively engaged in the work which is their specialty. Under no other conditions can the fullest efficiency be attained. Nor can it be attained with certainty unless these men are in the majority as regards either numbers or, at least, the weight effectively attached to their views.

When proved by these tests, of the three administrations here specially considered, only that of the Committee of the Privy Council seems to be of quite the fittest type. Although there is full internal evidence in the reports of the Carnegie Trusts that great weight is attached to expert advice, possibility should be changed into visible certainty: Nevertheless, one ought not to take cognisance of this condition without at the same time acknowledging, with full appreciation, the height of the aims of these trusts and the greatness of the results to which they have attained. W. PEDDIE.

ANTISEPTICS, AND THE TREATMENT OF INFECTED WOUNDS.

GROM the beginning of the war the Medical Research Committee has paid special attention to the important subject of antiseptics in the treatment of wounds. The part taken by Sir Almroth Wright and the bacteriological depart- 
ment of the committee is well known. At the same time the committee has supported independent inquiries in other directions, which fall under two main heads. The first group comprises the studies of the properties of hypochlorites and their derivatives. At Edinburgh Profs. Ritchie and Lorrain Smith produced and investigated the solution now widely known and used as "Eusol," in which the prefix is not Greek, as might be supposed, but stands for Edinburgh University. Simultaneously, Dr. Dakin, working in collaboration with Prof. Cohen, of the University of Leeds, and Dr. Carrel, in France, brought forward the now well-known "Dakin" hypochlorite solution, used widely for the French Army, for the British Army in France, and in America. Later, Dr. Dakin, working for the committee in its biochemical department, investigated the properties of paratoluene sulphochloramide, prepared earlier for him in Prof. Cohen's laboratory by a modification of Chattaway's original process. This antiseptic has already obtained wide use in England and France, under Dr. Dakin's name, "chloramine- $T$," and in America under the name "chlorazene." Being non-toxic and less unpleasant than hypochlorite solutions close to the nose, it has been specially useful in mouth and jaw cases, and from its property of ready adsorption by textiles, it provides antiseptic gauzes of far higher potency than those previously available.

The second group of inquiries supported by the committee has been concerned with benzene derivatives, and chiefly those already known to the synthetic dye industry. At a very early stage in the war, Surgeon-General Cheatle, with Drs. Fildes and Rajchman, investigated for the committee a series of compounds, of which they brought forward malachite green as having high value in the treatment of infected wounds. More recently, Dr. Carl Browning, working in the Bland-Sutton Institute of the Middlesex Hospital, who had previously worked with brilliant green and other synthetic dyes as weapons in the technique of bacteriological discrimination, has examined for the committee other synthetic dyes. Much interest has been taken in his statement of the antiseptic properties of what he proposes to call "flavine." This is an acridin derivative previously prepared and actually patented in Germany, to which Ehrlich gave the name "trypaflavin," on account of its trypanocidal properties.

Owing to the war, supplies of this substance were unobtainable, but Dr. Barger, in the biochemical department of the Medical Research Cpmmittee, prepared "trypaflavin" for the purposes of Dr. Browning's investigation, with the results already published. This, now called "flavine," Dr. Browning found to havé, in addition to high bactericidal potency, the very remarkable, and at present wholly unexplained, property of gaining, instead of losing, in potency in the presence of serum, and it has the further valuable property of appearing to leave undamaged the activities of phagocytes in dilutions which still have high bactericidal power.

NO. 2483, VOL. 99]
The committee has arranged for the manufacture of "flavine" upon a commercial scale for Government purposes, and as the new supplies become available it is hoped that complete clinical trials may be made of its value in the treatment of wounds. The preliminary reports already received from surgeons, based upon the first results of the laboratory manufacture, are most encouraging.

\section{HOME-GROWN SUGAR.}

THE announcement in the Times of April Ig that the Treasury has sanctioned a grant of $125,000 l$. by way of loan from the Development Fund towards the purchase of an estate for the purposes of sugar-beet growing and sugar manufacture marks an advance of the highest importance towards the establishment in this country of this valuable industry.

For many years an active propaganda directed towards this end has been carried on, and much valuable preliminary investigation has been completed. Numerous experiments in different parts of the country have shown conclusively that over wide areas sugar-beet crops fully equal in yield and quality to those of the Continent can be grown, and the ground has been effectively cleared for putting the possibilities of the industry to practical test.

For several reasons, however, previous efforts to establish the industry have met with but scant success. On one hand the uncertainty as to national policy in relation to the once vexed question of sugar bounties has been a potent inhibiting factor, whilst on the other the necessary establishment of sugar-beet growing areas round the factory to give an assured supply of beets has also presented the greatest difficulties.

Repeated efforts to obtain State assistance have encountered the obstacle that such assistance could be given only to enterprises from which the element of private profit was entirely eliminated. At long last, however, the efforts appear to be within sight of fruition, and with the more clearly realised need for the establishment of the industry and the closer consideration given to the solution of the difficulties involved, a scheme has been devised which Lord Selborne's committee in its interim report felt able to endorse as well thought out and sound.

This enterprise for which Treasury support has been obtained is to be carried out by the British Sugar-Beet Growers' Society, Ltd., an organisation not trading for profit, and created specifically for the purposes of the scheme, with Capt. Beville Stanier, M.P., as chairman, and an influential and representative committee, with expert advisory assistance. Through the vicechairman, Mr. E. Jardine, M.P., an estate of 5600 acres has been acquired at Kelham, near Newark, where it is proposed to grow a large area of sugar-beet and to erect a factory for its manufacture into sugar. The estate is very favourably situated for both rail and canal 